\title{
Novos objectivos e desafios para o futuro da Revista Motricidade
}

\author{
New goals and challenges for the future of Journal Motricidade
}

\author{
J. Vasconcelos-Raposo, H.M. Fernandes
}

Direcção da Revista Motricidade - Universidade de Trás-os-Montes e Alto Douro

A Revista Motricidade, de 2009 até hoje, cresceu a um ritmo acelerado. No momento em que escrevemos este editorial a Revista Motricidade ultrapassou as 100.500 entradas só no seu site e que resultaram de uma busca específica com a palavra motricidade. Este é um facto, talvez de menor importância para os nossos leitores, mas particularmente gratificante para quem dedica uma boa parte da sua vida ao projecto de reabilitar e redimensionar esta revista científica. A nossa satisfação advém, também do facto de ter aumentado expressivamente o número de submissões à nossa revista, sendo de destacar o nível dos pesquisadores que nos honram, seleccionando-nos como meio privilegiado para divulgar os seus trabalhos. Por último, importa realçar o reconhecimento que temos tido através da aceitação por algumas das mais prestigiadas bases internacionais de indexação e resumos.

Temos, ao longo da nossa gestão, procurado por novos desafios e expormo-nos a patamares de exigência cada vez maiores. Neste percurso, beneficiámos do apoio de todos aqueles que constam do nosso corpo editorial e por tal facto estamos gratos. A Motricidade manteve-se fiel ao seu princípio de procurar ser um veículo para o encorajamento e divulgação dos trabalhos dos novos pesquisadores talentosos que emergem na comunidade científica da Lusofonia.

A Revista e o seu reconhecimento pelos pares, neste curto período, fez com que tivéssemos sido mais que transmissores de saber na forma de publicação; fomos, também, a plataforma que alguns encontraram na nossa revista, através da publicação dos seus trabalhos, para promoverem as revistas de que eram dirigentes e assim, graças ao prestígio da Motricidade puderam ver os seus periódicos avaliados de forma mais positiva. Nada disto aconteceu de forma propositada ou planeada da nossa parte, mas ao analisarmos os detalhes da vida da revista relativamente a tudo o que lhe diz respeito, esta prática utilitária tornou-se evidente.

Ainda só decorreram dois anos, e já chegou mais um momento de nos renovarmos e, assim, no ano de 2012, o nosso corpo editorial terá uma nova composição e a nossa estrutura de gestão será renovada e apresentará uma nova estrutura funcional. A todos os que optaram por não nos acompanhar nesta etapa renovada, claramente mais exigente para todos, desde já fica o nosso reconhecimento e apreço pelo inestimável contributo que nos deram, sem o qual não poderíamos ter crescido ao ritmo que o fizemos. Uns, mais do que outros, voluntariamente prejudicaram a sua carreira académica ao aceitarem ser revisores e membros do corpo editorial sem que para tal tenham recebido qualquer forma de agraciamento que não fosse o nosso sincero OBRIGADO.

Até este momento, todos os dirigentes da Motricidade aceitaram participar nela assumindo que tal facto os impede de a terem como revista de escolha para divulgar os seus trabalhos. Agora, para aqueles que nos deixarão poderão ter-nos como mais uma das revistas onde podem divulgar os conhecimentos por si gerados. Assim esperamos.

Num século onde cada vez mais a via electrónica surge como a privilegiada para ter 
acesso a todo o tipo de informação, incluindo o especializado, como é o caso do conhecimento científico, o formato de papel vem a consolidarse como um meio complementar dos formatos digitais/on-line. Face a esta constatação, em 2012 daremos início a um processo experimental de gestão e edição electrónica e, com essa alteração, procuraremos melhorar a relação entre editores e autores, bem como, aumentar o número de artigos por número.
Como áreas de intervenção a Motricidade definiu as da Saúde, Desporto, Desenvolvimento Humano e Psicologia. No entanto, a actual estrutura funcional não se tem apresentado como a mais eficaz para implementar esta política, daí a necessidade de nos adequarmos e renovarmos para dar uma resposta mais eficaz.

Com estas alterações procuraremos melhor servir aqueles que nos procuram.

(cc) EY-No Todo o conteúdo da revista Motricidade está licenciado sob a Creative Commons, excepto quando especificado em contrário e nos conteúdos retirados de outras fontes bibliográficas. 